\title{
Exploring the risk/benefit balance in biomedical research: some considerations
}

Derrick E. Aarons

\begin{abstract}
Risk and benefit assessment is one of the fundamental requirements in the ethical review of research involving human participants. As a result, researchers should evaluate and seek to minimize all foreseeable risks involved in their proposed research and members of research ethics committees should evaluate and balance the risks and potential benefits involved in each research proposal as a part of their ethical obligations regarding research protocols. However, current literature provides little detailed guidance on the specifics of how this balancing process should occur. Consequently, this article provides some details of the process to balance risks and benefits in biomedical research and reminds members of research ethics committees of their responsibility to protect those who are vulnerable from exploitation in research projects.

Keywords: Research subjects-Protocols-Ethics. Human experimentation. Ethics Committees, research. Research design. Health vulnerability.
\end{abstract}

\section{Resumo}

\section{Explorando o balanceamento entre riscos e benefícios em pesquisa biomédica: algumas considerações}

A avaliação de riscos e benefícios é um dos requisitos fundamentais na revisão ética da pesquisa envolvendo participantes humanos. Consequentemente, os pesquisadores devem avaliar e procurar minimizar todos os riscos previsíveis envolvidos nas pesquisas propostas e os membros dos comitês de ética em pesquisa devem avaliar e balancear os possíveis riscos e benefícios envolvidos em cada proposta de pesquisa como parte de suas obrigações éticas em relação aos protocolos de pesquisa. No entanto, a literatura atual fornece poucas orientações detalhadas sobre como especificamente esse processo de balanceamento deve ocorrer. Consequentemente, este artigo fornece alguns detalhes do processo de balanceamento de riscos e benefícios na pesquisa biomédica e lembra aos membros dos comitês de ética de pesquisa de sua responsabilidade de proteger os vulneráveis da exploração em projetos de pesquisa.

Palavras-chave: Sujeitos da pesquisa-Protocolos-Ética. Experimentação humana. Comitê de ética em pesquisa. Projetos de pesquisa. Vulnerabilidade em saúde.

\section{Resumen}

\section{Explorando el balance riesgos/beneficios en la investigación biomédica: algunas consideraciones}

La evaluación de riesgos y beneficios es uno de los requisitos fundamentales en la revisión ética de la investigación con participantes humanos. Como resultado, los investigadores deben evaluar e intentar minimizar todos los riesgos previsibles involucrados en la investigación propuesta, y los miembros de los comités de ética en investigación deben evaluar y hacer un balance de los riesgos y beneficios potenciales implicados en cada propuesta de investigación como parte de sus obligaciones éticas respecto de los protocolos de investigación. Sin embargo, la literatura actual proporciona escasas guías sobre los detalles específicos de cómo debe ocurrir este proceso de equilibrio. En consecuencia, este artículo ofrece algunos detalles del proceso para equilibrar los riesgos y beneficios en la investigación biomédica y les recuerda a los miembros de los comités de ética de investigación su responsabilidad de proteger a aquellos que son vulnerables a la explotación en proyectos de investigación.

Palabras clave: Sujetos de investigación-Protocolos-Ética. Experimentación humana. Comité de ética en investigación. Proyectos de investigación. Vulnerabilidad en salud.

PhD aaronsderrick27@gmail.com - The Caribbean Public Health Agency. Port of Spain, Trinidad \& Tobago.

\section{Correspondência}

The Caribbean Public Health Agency, 16-18 Jamaica Blvd Federation Park. Port of Spain, Trinidad \& Tobago.

Declara não haver conflitos de interesse. 
All biomedical research with human participants should undergo a priori review by a recognized research ethics committee ${ }^{1}$. The chairperson of the committee will determine whether the research proposal requires a full review by all committee members, whether it qualifies for expedited review by a few committee members, or whether the research proposal falls into the category of exemption from ethics review. On submission to the research ethics committee (REC/IRB), REC members should make an adequate assessment of the research proposal, ensuring that the seven ethical requirements for research with human subjects are met ${ }^{2}$. These requirements include a determination of the possible value of the research, the scientific validity of the proposed methodology, a fair selection process for research participants, a favorable balance of the foreseeable risks and possible benefits of the research endeavour and an evaluation regarding the welfare of the proposed research participants. The latter concept includes ensuring that all participants are respected throughout the research process, that their personal information will be effectively safeguarded (confidentiality), and that the informed consenting process meets internationally accepted standards ${ }^{3}$.

A review of the published literature revealed that much discussion has occurred regarding risks and benefits in research, however, no publication was found that could guide research ethics committee members and researchers regarding the detailed determination of risk, its levels and possible categories, and specifically how to balance these risks and potential benefits (whether to individuals, communities, or to a country or society). This article therefore seeks to provide detailed guidance on some of these issues, against the background of possible exploitation in some research endeavours.

\section{What is 'risk' in research?}

Risk in research is the probability of harm, loss, injury or other adverse consequence occurring to someone as a result of their participation in a research study ${ }^{4}$. Customarily, when any risk of harm is mentioned, physical harm instantly comes to mind, and people usually only think about the risk of physical injury to their person. However, the concept of harm has more than one dimension. Researchers, research ethics committee members, and possible research project participants should therefore be aware that harm, which may occur during research projects, includes aspects such as physical, moral, psychological, social, legal, and financial harm.

The risk of physical harm includes a risk of illness, injury, pain, and others ailments that are associated with physical well-being (e.g. injury during invasive medical procedures or from possible side-effects of a research drug) ${ }^{4}$. The concept of moral harm begins with a respect for the person and their well-being, with specific recognition and respect being paid to a person's dignity and body integrity ${ }^{5}$. The underlying issue here is that all human beings have moral worth, and through the nature of that moral worth, respect is due to them, their dignity, and their body integrity. As a result, people should have full control over their bodies, their personal information, and their body tissue. If one wishes to use their information or body tissue for research (e.g. tissue extracted during routine or emergency surgery), even if anonymously, that information or body tissue is theirs, so their permission should be sought in advance. Failure to do so is to cause moral harm to their dignity and integrity.

Risk of psychological harm includes the risk of production of negative states or altered behavior, including anxiety, depression, guilt, shock, feelings of worthlessness, anger or fear ${ }^{4}$. These can occur if research participants are required to recall painful events, learn about the genetic possibility of developing an untreatable disease, or if participants feel threatened or stressed as a result of their involvement in the research.

Risk of social harm includes a possible risk involving the disruption of research participants' social networks (families, friends, associates, civic and religious communities) or a change in their relationships with others, and may involve stigmatization, embarrassment, or a loss of respect. It may occur, for example, if there is an inadvertent disclosure of sensitive or embarrassing information (e.g. HIV infection or mental illness). A risk of legal harm includes the risk of discovery of and prosecution for criminal conduct, for instance, if information about illegal substance abusers were revealed to the police ${ }^{4}$.

Risks of financial or economic harm include the risk of an incurrence or the imposition of financial burdens, hardships or direct or indirect financial costs for participants due to their involvement in the research project. This can occur, for example, if a person's HIV-positive status is inadvertently disclosed during the research process, resulting in the affected research participant losing their employment or access to insurance benefits. 


\section{Levels of risks}

'Risk' is a word expressing 'probabilities', and when used in relation to research, it is expressing the probability of harm occurring during the research endeavour. In this regard, risks in biomedical research may be classified as minimal, low, medium and high risk ${ }^{4}$.

\section{Minimum risk}

This is in fact the least possible risk. There is no category such as 'no risk', since once patients are involved in research, at the very least they lose personal time, which they might otherwise be spending in their personal life pursuits or endeavours. Involvement in research and its outcome uncertainty also carries at the very least some minimal degree of apprehension for research participants, so it has psychological consequences. As a result, research proposals should never state that 'no risk is involved'.

Procedures that may be classified as minimal risk include questioning, observing and measuring research participants in an area or subject that is not controversial, provided that the procedures are carried out in a sensitive way and that consent has been given ${ }^{6}$. In biomedical research, this category also includes the collection of a single urine sample and using blood from a sample that had already been taken as a part of routine health care management. Most projects in cultural and social science research are generally classified as minimal risk because they usually involve very little risk of physical harm ${ }^{7}$. However, due to possible risk of significant psychological harm occurring in some research, such as those exposing research participants to very strong stimuli (e.g. studies containing violence or pornography), or if they may cause long-term mental harm (e.g. depression, sleeplessness) beyond the risks encountered in normal life, then those projects may deserve classification into other categories, depending on the particular circumstances ${ }^{8}$. Some social science research projects may even deserve being classified as high risk if the research carries a significant security risk to participants (e.g. domestic violence with risk of death) ${ }^{8}$.

\section{Low risk}

In this category of biomedical research, one would insert procedures whose use during the research process may cause brief pain or tenderness, or small bruises and possibly small scars ${ }^{6}$. We should note that when children are involved in research, they are invariably apprehensive, so any use of needles during the research process, whether for injections, venipuncture or otherwise, will automatically incur a categorization of low rather than minimal risk.

\section{Medium risk}

This category describes procedures used during research that involve risks that are intermediary between 'low' and 'high' risk, and such judgements are best made by a research ethics committee. Note that biomedical research that involves, for example, one or two radiographic (X-ray) pictures taken of the abdomen of a pregnant woman would carry more than low risk to the fetus, but the research may still be allowed by the research ethics committee if there is a commensurate greater benefit to be obtained for the particular pregnant woman from the outcome of the research.

\section{High risk}

In biomedical research, this category of risk usually involves research that using procedures such as lung or liver biopsy, arterial puncture, or cardiac catheterization, procedures that normally cannot be justified for research purposes alone. Such procedures for research should only be carried out when the research is combined with diagnosis and treatment that is intended to benefit the particular research participants concerned. Clinical trials using experimental treatment agents are also classified as high risk ${ }^{6}$.

\section{Benefits of research}

'Benefit' is a word expressing a fact or state of affairs, so when this term is used during research planning or the stages of ethics review, people should really use the term 'possible benefit' or 'potential benefits', since the outcome is anticipated and not a fact. We should also note that in research, benefits might accrue in more than one area. They might occur only in the individual (concrete benefits to research participants) or may result in a benefit to society (when research is viewed as a social good, for the benefit of current and future generations). Research should never be allowed to proceed unless there is an indication of some anticipated or potential benefit, whether that outcome benefit is new knowledge or confirmation of the results of other research previously conducted. 
The Council for International Organizations of Medical Sciences (CIOMS) publishes the CIOMS International Guidelines, ${ }^{3}$ which state that a variety of interventions may be involved in research, some of which may have possible direct therapeutic benefits, while other research may involve non-beneficial interventions, such as when research is done solely to answer a research question. Thus, possible benefits from research include gaining knowledge, insight and understanding, as well as possible gains in skill, kudos, or expertise for the researchers or the research institution. Individual research participants may physically benefit through direct social welfare or through institutions that support their well-being.

Research may also benefit a local community ${ }^{3}$. In biomedical research, this includes better health services, improved lives and livelihood for members of the community, a reduced patient burden on the health care system, solutions to health care problems, a curtailing of increasing health care costs and the creation of a knowledge-intensive health care industry ${ }^{4}$.

\section{The assessment of risks \& benefits}

Both the 'probability' of risks as well as the 'magnitude' of possible harm must be considered at this stage. This means the probability or likelihood that harm will occur and the magnitude of the harm, including its consequences ${ }^{4}$. Therefore, when making this assessment, we should ask: How likely is this particular harm to occur (probability)? After answering that question, we should then ask: How large is this harm likely to be, if it occurs (magnitude)? What effect is it likely to have? We would then compare 'predictable' risks to 'foreseeable' benefits!

For research proposals to meet this ethical requirement, a favorable risk to benefit ratio must exist. In other words, the risks must be lower than the anticipated benefits or the expected benefits must outweigh the risks. In other words, the benefits that may accrue to the individual or to the society must outweigh the potential risks to the research participants. More importantly, the more likely or more severe the potential risks, the greater the magnitude of the prospective benefits should be ${ }^{4}$.

In conducting this determination, research ethics committees should be aware that some biomedical research may offer direct benefits to research participants, such as those who are suffering from a particular illness who may be amenable to the treatment being tested. In the latter scenario, the participants may be willing to accept risks or treatment side-effects that would have likely been deemed unacceptable by others who are not suffering from the particular disease. Consequently, assessing risks and benefits requires an exercise of good judgment and should be based on the available information in the research protocol as well as a full appreciation of the context ${ }^{4}$. All such determinations should be transparent and defensible.

Allied thereto is the consideration of whether the proposed biomedical research will continue to provide the tested treatment to research participants when the research project has ended, particularly when local health care services do not provide such treatments. This is an important justice issue for participants involved in health research in Southern countries (lower and middle income countries - LMIC), and becomes even more crucial when participants are near the end of life and their health condition is incurable. Research ethics committees should deliberate deeply on these issues when evaluating such research proposals.

\section{Steps in the risk/benefit balance}

To arrive at a judgment regarding the ethical acceptability of the risks in proposed research, it is essential that members of research ethics committees identify all the risks and who will be affected ${ }^{4}$. This assessment will include possible effects on research participants, but may at times also involve assessing the risk to others existing outside the research scope (e.g. in genomic research projects whose results may affect family members of research participants). The committee must assess the likelihood and magnitude of the risks, as well as the extent to which the risks may be minimized. Committee members must then identify the potential benefits that might reasonably be expected, and to whom such benefits are likely to accrue, whether to participants and/or others. The research ethics committee should then exercise its judgment on the matter, and balance the two sides of the issue!

\section{Some ways to minimize risks}

Risks must be minimized using procedures that are consistent with sound research design. This will vary with the particular methodology used, however that should be the uppermost goal during the design stages of the research. For example, in assessing the research design, we should note that 
an inappropriate sample size may not lead to any meaningful results and would affect the magnitude of possible benefits. Here, there would be a risk of wasting research participants' time, plus exposing them to research whose outcome may not be accepted by the wider scientific community.

The project should therefore gather an experienced research team that is sufficient to successfully carry out the proposed work. This would be particularly important for biomedical research involving invasive procedures, in order to minimize physical harm. Such a project should also include trained personnel who can respond to possible emergencies. A safety monitoring plan should also be placed into effect, which would include the protection and confidentiality of the data collected ${ }^{4}$.

\section{Exploitation in biomedical research}

Health and biomedical research seeks to benefit all members of society, but greater attention should be given to those research endeavours that involve those who may be considered vulnerable or disenfranchised ${ }^{9}$. Vulnerability indicates a state of being exposed, being easily hurt, or being susceptible to physical harm or emotional injury ${ }^{10,11}$.

Thus, people may be classified as being 'vulnerable' if they have a reduced ability to protect themselves and their personal affairs ${ }^{12}$. They may not have enough education or intelligence, political power, resources, strength or other attributes that are needed to protect their own best interests. The CIOMS International Guidelines specifically state that special justification must be provided for inviting vulnerable persons to participate in research, and if they are selected, then there should be adequate protection of their rights and welfare ${ }^{3}$.

Health research should also seek to benefit and prioritize those whose health is relatively worse off, due to their disenfranchised position in the lower socio-economic strata of society ${ }^{9}$. The prevailing socio-economic systems in many low and middle-income countries are shaped and driven by capitalism and capitalist inclinations by those in power within those societies. In many of those systems, the private sector's main and sometimes sole interest is in maximizing profits for itself and its shareholders. It therefore behooves the state and civil society to seek to cushion the full effects of economic policies that do not seek benefit or guarantee the welfare for those in the lower socio-economic strata of the society. In these circumstances, biomedical research should focus on what ameliorating practical interventions could be made on their behalf, in order to elevate their health and socio-economic status. Priority should then be given to this type of research ${ }^{9}$.

The major ethical issue in situations of vulnerability and disenfranchisement is the matter of justice, which requires that there be an equitable distribution of the benefits and burdens of research. No group should bear excessive burdens, while others receive benefits without sharing equally in the burdens. There are specific persons or groups that are traditionally considered to be vulnerable, as they have limited mental capacity or limited freedom to consent or to decline participation in research ${ }^{3}$.

This group includes children and those with mental or behavioral disorders that render them incapable of providing informed consent. People with good mental capacity may still be regarded as being in vulnerable situations, such as when they are in junior positions in a hierarchical group or society, or are institutionalized in situations that limit their autonomy and decision-making. Examples of these also include students involved in health care or research training, employees in pharmaceutical companies, members of a country's national security forces or the elderly in nursing homes.

Despite all the foregoing, however, biomedical research at times needs to include such subjects, as they and their particular ailment may benefit from the outcome of the particular research endeavour (e.g., pregnant women who may benefit from research on particular drugs or vaccines). Depending on the circumstance, vulnerable persons should not be excluded from research, but instead extra precautions should be undertaken to protect them and their welfare ${ }^{12}$. Further, because these people are vulnerable, they should be protected from exploitation.

Exploitation refers to a state of affairs where a person or people in positions of power and influence unfairly take advantage of a person or group's vulnerability in order to profit or benefit themselves ${ }^{13-15}$. Exploitation may occur at an individual level or it may involve a group, a community, or a population ${ }^{16}$. When we consider possible exploitation in research, we should be cognizant that many LMIC Southern countries have relatively more uneducated, dis-empowered, and disenfranchised people than countries of the North, and so a relatively greater emphasis should be placed on the ethical principle of justice, rather than on the North American notion of autonomy ${ }^{16}$. 
A person's autonomy should always be respected, and a person's informed consent to research should always be obtained and documented, but when research ethics committees are evaluating proposed multi-centre research involving countries of the North and LMIC, they should place a greater emphasis on the matter of justice in the proposed research, while ensuring the documentation of informed consent. In other words, research ethics committees have the responsibility to evaluate research proposals to ascertain whether what sponsors and potential researchers are proposing to do is fair to research participants and their communities. This should occur regardless of whether these subjects might or might not be giving supposed informed consent.

Justice also requires that research ethics committees ensure that biomedical research reflects the health needs of the particular community that will be involved in the research ${ }^{3}$. Consequently, research ethics committee members should ask themselves: 1) In the proposed research, are the research participants being exploited? 2) Is there a fair balancing of the benefits, burdens, and risks for these research participants? 3) Is their community being over-researched? 4) If there will be no direct benefits to the participants, will their local community or society benefit from the research?

Current and historic asymmetry of resources and influence between countries of the North and countries of the South have made many LMIC Southern countries 'vulnerable' and therefore more susceptible to exploitation ${ }^{16}$. Researchers, sponsors, governments in host countries, as well as local research ethics committees should therefore be sensitive to all these issues and seek to protect all people from possible exploitation in biomedical research.

\section{Discussion}

Research ethics committees are required to assess the level of risk to research participants, determine the possible benefits from the research, and weigh and balance these two foreseeable potentials to determine whether the particular research proposals should be approved or disapproved. Research participants should be protected from excessive risks, so a systematic framework to assess risks should exist rather than researchers and research ethics committee members depending on their own intuitive judgements ${ }^{17}$.
International research ethics guidelines state that clinical research is only ethical when the research risk to participants is reasonable ${ }^{18,19}$. For each research proposal, research ethics committee members should thus determine whether more than one category of risk may arise in the particular research (e.g. risk of physical harm, psychological harm, social harm, financial or economic harm or legal harm). They should then determine the level of risk (minimal, low, medium or high) for each of the possible category types identified in the proposed research. Each identified category of risk with its commensurate level of risk should be listed or delineated on a chart.

Committee members should then seek to determine the possible benefits, if any, from the proposed research. Special care should be taken as social benefits may sometimes be uncertain ${ }^{20}$. These may be stated in the particular research proposal, but committee members should make such a determination for themselves. Documentation should be made of whether the potential benefits of the research would accrue to the research participants or to the society, as well as whether that potential benefit is in the form of new knowledge or the confirmation of previous research. Delineation should be made regarding whether the research participants may directly benefit, or whether they might benefit indirectly through possible improvements to institutions that support their well-being.

Research ethics committee members should also seek to identify whether any benefit might accrue to the local communities from which the particular research participants may come, which could take the form of improvement in local health services that would benefit the lives and livelihood of other members of the local community. Documentation of any potential benefits to the wider society should also be made and this may take the form of increased knowledge and insights that may spawn new research into related fields.

Considering all of the above, committee members should then proceed to evaluate the likelihood of those identified risks occurring and the possible magnitude of effects they would have if those risks materialize. A similar determination should be made for the possible benefits arising from the research project ${ }^{21}$. All risk-benefit analyses should involve a quantitative judgement of all perceived risks, what may be considered as acceptable risks, and what are the perceived benefits ${ }^{22}$. The predictable risks and the reasonably anticipated 
benefits of the particular research endeavour should then be analytically compared on paper or visually on a chart, focused on determining whether the anticipated benefits are so large in their magnitude and scope as to outweigh the various predictable risks of harm with their possible magnitude effect, should they occur. Research ethics committees may then proceed to approve those proposals having the preponderance that the likelihood and magnitude of the potential benefits arising from the research will outweigh the likelihood and magnitude of harms if they occur, once all the other ethical requirements for biomedical research have been met.

\section{Final considerations}

Researchers, in preparing informed consent documents for participant enrolment and protocols for ethical review, should seek to denote all foreseeable risks associated with their research projects ${ }^{23}$. Any potential benefits identified in the document should be clearly stated as referring to the individual research participants, their health care system (or similar), people in their local community, or for the wider society. Ethical weights will have to be given to the relevant considerations in the balancing process.

Research ethics committees should also consider issues of justice and ensure that the research reflects the health needs of the population to be researched. It will be the responsibility of research ethics committees to ensure that communities within their particular jurisdiction are not over-researched, and they should not approve research where participants may be exploited. Particularly in low and middle-income countries of the South, proposed research should either directly benefit the research participants, their local community or society as a whole.

\section{Referências}

1. Aarons D. Research ethics. West Indian Med J. 1995;44(4):115-8.

2. Emanuel EJ, Wendler D, Grady C. What makes clinical research ethical? Jama. 2000;283(20):2701-11.

3. Council for International Organizations of Medical Sciences. International guidelines for biomedical research involving human subjects. Geneva: CIOMS; 2016 [acesso 20 fev 2017]. Disponível: http://bit.ly/2p7Mwar

4. Aarons DE. Risk/benefits balance and exploitation in biomedical research. Annals of the $6^{\text {th }}$ International Congress of RedBioetica/Unesco. Costa Rica: Ministry of Health; 2016.

5. Aarons D. Ethical issues surrounding body integrity and research. West Indian Med J. 2014;63(5):399-400b.

6. Caribbean Public Health Agency. Research ethics committee. CARPHA. Trinidad \& Tobago; 2014 p. 11.

7. The National Committee for Research Ethics in the Social Sciences and the Humanities. Guidelines for Research Ethics in the Social Sciences, Law and the Humanities. Norway; 2006. p. 12.

8. National Advisory Board on Research Ethics. Ethical principles of research in the humanities and social and behavioural sciences and proposals for ethical review. The National Advisory Board on Research Ethics' Proposals. Helsinki; 2009. p. 3.

9. Aarons DE. Research: an ethical answer in addressing our people's health problems and inequities. West Indian Med J. 2015:64(Suppl 2);97-100.

10. Straehle C. Vulnerability, health agency and capability to health. Bioethics. 2016;30(1):34-40. DOI: 10.1111/bioe.12221

11. Arora SK, Shah D, Chaturvedi S, Gupta P. Defining and measuring vulnerability in young people. Indian J Community Med. 2015 [acesso 22 fev 2017];40(3):193-7. DOI: 10.4103/0970-0218.158868

12. Aarons DE. Issues in bioethics: teaching research ethics. West Indian Med J. 2003;52(2):145-50.

13. Pratt B, Lwin KM, Zion D, Nosten F, Loff B, Cheah PY. Exploitation and community engagement: can advisory boards successfully assume a role minimising exploitation in international research? Dev World Bioeth. 2015 [acesso 22 fev 2017];15(1):18-26. DOI: 10.1111/dewb.12031

14. Dal-Ré R, Rid A, Emanuel E, Wendler D. The potential exploitation of research participants in high income countries who lack access to health care. Br J Clin Pharmacol. 2016 [acesso 22 fev 2017];81(5):857-64. DOI: 10.1111/bcp12879

15. Snyder J. Exploitations and their complications: the necessity of identifying the multiple forms of exploitation in pharmaceutical trials. Bioethics. 2012 [acesso 22 fev 2017];26(5):251-8. DOI: $10.1111 /$ j.1467-8519.2010.01847

16. Aarons DE. Family health, public health, and vulnerability in research: a caribbean perspective. Revista Redbioética/Unesco. 2016;7(14).

17. Rid A, Emanuel EJ, Wendler D. Evaluating the risks of clinical research. Jama. 2010;304(13):1472-9.

18. Wendler D, Miller FG. Assessing research risks systematically: the net risks test. J Med Ethics. 2007;33(8):481-86. 
19. Weijer C, Miller PB. Refuting the net risks test: a response to Wendler and Miller's 'Assessing research risks systematically.' J Med Ethics. 2007;33(8):481-6.

20. Miller FG, Joffe S. Limits to research risks. J Med Ethics. 2009;35(7):397-9.

21. Weijer $\mathrm{C}$, Miller PB. When are research risks reasonable in relation to anticipated benefits? Nat Med. 2004;10(6):570-3.

22. Fischhoff $B$, Slovic $P$, Litchtenstein $S$, Read $S$, Combs B. How safe is safe enough? A psychometric study of attitudes towards technological risks and benefits. Policy Sciences. 1978;9(2):127-52.

23. Renn O. Three decades of risk research: accomplishments and new challenges. J Risk Res. 1998 [acesso 2 mar 2017];1(1):49-71. Disponível: http://dx.doi.org/10.1080/136698798377321

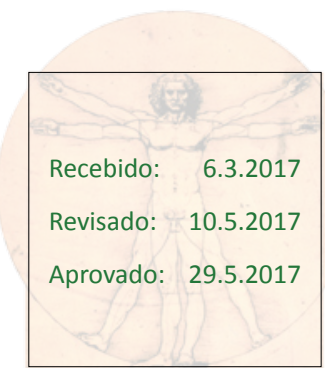

